\title{
Correction to: High sensitivity troponin $T$ and I reflect mitral annular plane systolic excursion being assessed by cardiac magnetic resonance imaging
}

Michèle Natale ${ }^{1}$, Michael Behnes ${ }^{1 *}$, Seung-Hyun Kim ${ }^{1}$, Julia Hofmann ${ }^{1}$, Nadine Reckord ${ }^{1}$, Ursula Hofmann ${ }^{1}$, Johannes Budjan², Siegfried Lang ${ }^{1}$, Martin Borggrefe ${ }^{1}$, Theano Papavassiliu', Thomas Bertsch ${ }^{3}$ and Ibrahim Akin'

\section{Correction to: Eur J Med Res (2017) 22:38} https://doi.org/10.1186/s40001-017-0281-x Following publication of the original article [1], the authors reported that there was a mistake in the Methods section $\rightarrow$ Measurements of biomarkers (page 6, line 3): $2000 \mathrm{~g}$ should read $2500 \mathrm{~g}$. So, the correct sentence should be "All samples were obtained by venipuncture into serum monovettes ${ }^{\circledR}$ and centrifuged at $2500 \mathrm{~g}$ for $10 \mathrm{~min}$ at $20^{\circ} \mathrm{C}$."

\section{Author details}

${ }^{1}$ First Department of Medicine, Faculty of Medicine Mannheim, University Medical Center Mannheim (UMM), University of Heidelberg, Theodor-Kutzer-Ufer 1-3, 68167 Mannheim, Germany. ${ }^{2}$ Institute of Clinical Radiology and Nuclear Medicine, Faculty of Medicine Mannheim, University Medical Center Mannheim (UMM), University of Heidelberg, Mannheim, Germany. ${ }^{3}$ Institute of Clinical Chemistry, Laboratory Medicine and Transfusion Medicine, General Hospital Nuremberg, Paracelsus Medical University, Nuremberg, Germany.
The original article can be found online at https://doi.org/10.1186/ s40001-017-0281-x.

\section{Publisher's Note}

Springer Nature remains neutral with regard to jurisdictional claims in published maps and institutional affiliations.

Received: 8 February 2018 Accepted: 8 February 2018

Published online: 19 February 2018

\section{Reference}

1. Natale M, Behnes M, Kim S-H, Hofmann J, Reckord N, Hofmann U, Budjan J, Lang S, Borggrefe M, Papavassiliu T, Bertsch T, Akin I. High sensitivity troponin $T$ and I reflect mitral annular plane systolic excursion being assessed by cardiac magnetic resonance imaging. Eur J Med Res. 2017;22:38. https://doi.org/10.1186/s40001-017-0281-x.

\footnotetext{
*Correspondence: michael.behnes@umm.de

${ }^{1}$ First Department of Medicine, Faculty of Medicine Mannheim,

University Medical Center Mannheim (UMM), University of Heidelberg,

Theodor-Kutzer-Ufer 1-3, 68167 Mannheim, Germany

Full list of author information is available at the end of the article
} provided you give appropriate credit to the original author(s) and the source, provide a link to the Creative Commons license, and indicate if changes were made. The Creative Commons Public Domain Dedication waiver (http://creativecommons.org/ publicdomain/zero/1.0/) applies to the data made available in this article, unless otherwise stated. 